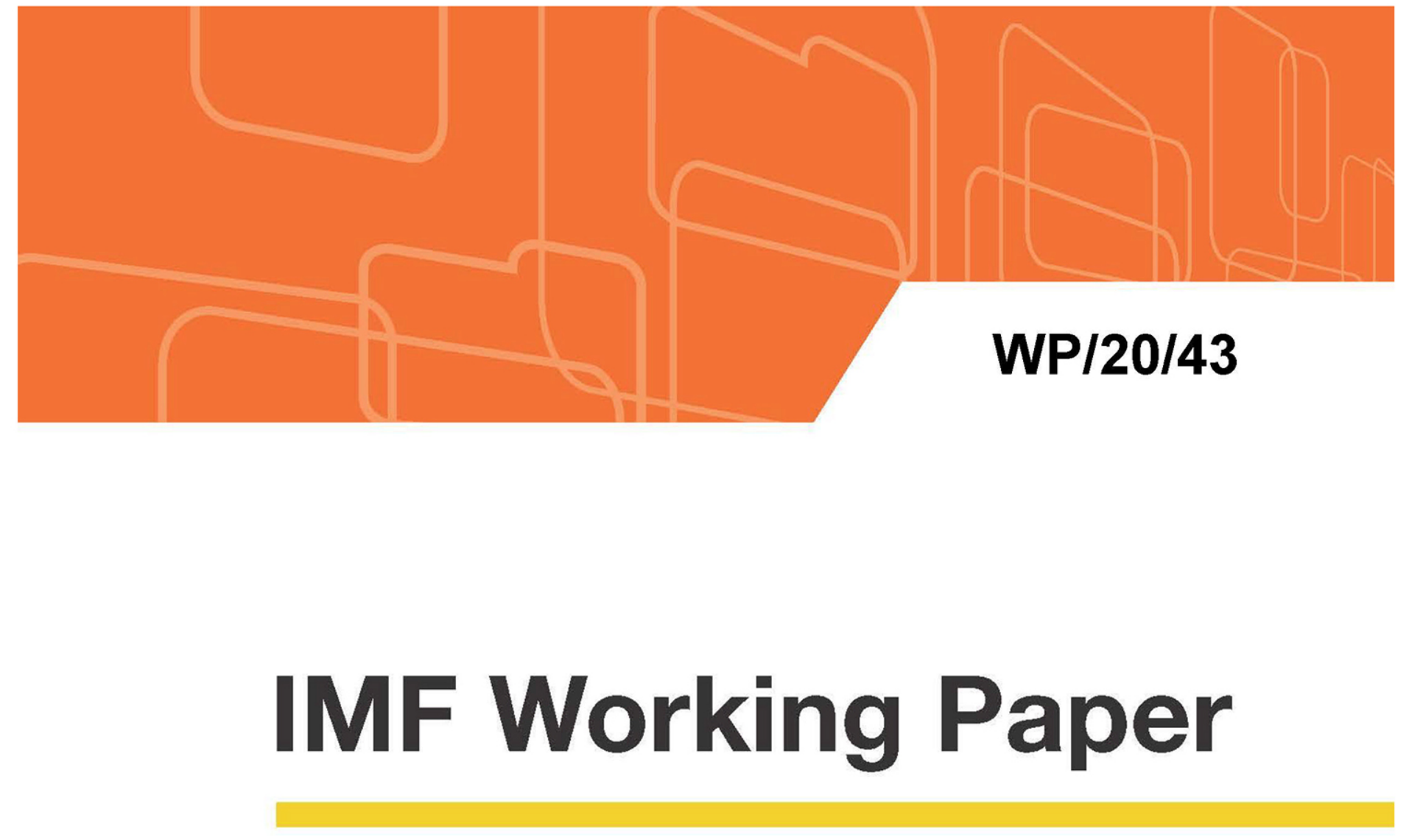

\title{
Foreign Demand and Local House Prices: Evidence from the US
}

by Anil Ari, Damien Puy, Yu Shi

IMF Working Papers describe research in progress by the author(s) and are published to elicit comments and to encourage debate. The views expressed in IMF Working Papers are those of the author(s) and do not necessarily represent the views of the IMF, its Executive Board, or IMF management.

$$
\text { I N T ER N A T I O N A L M O N E T A R Y F U N D }
$$




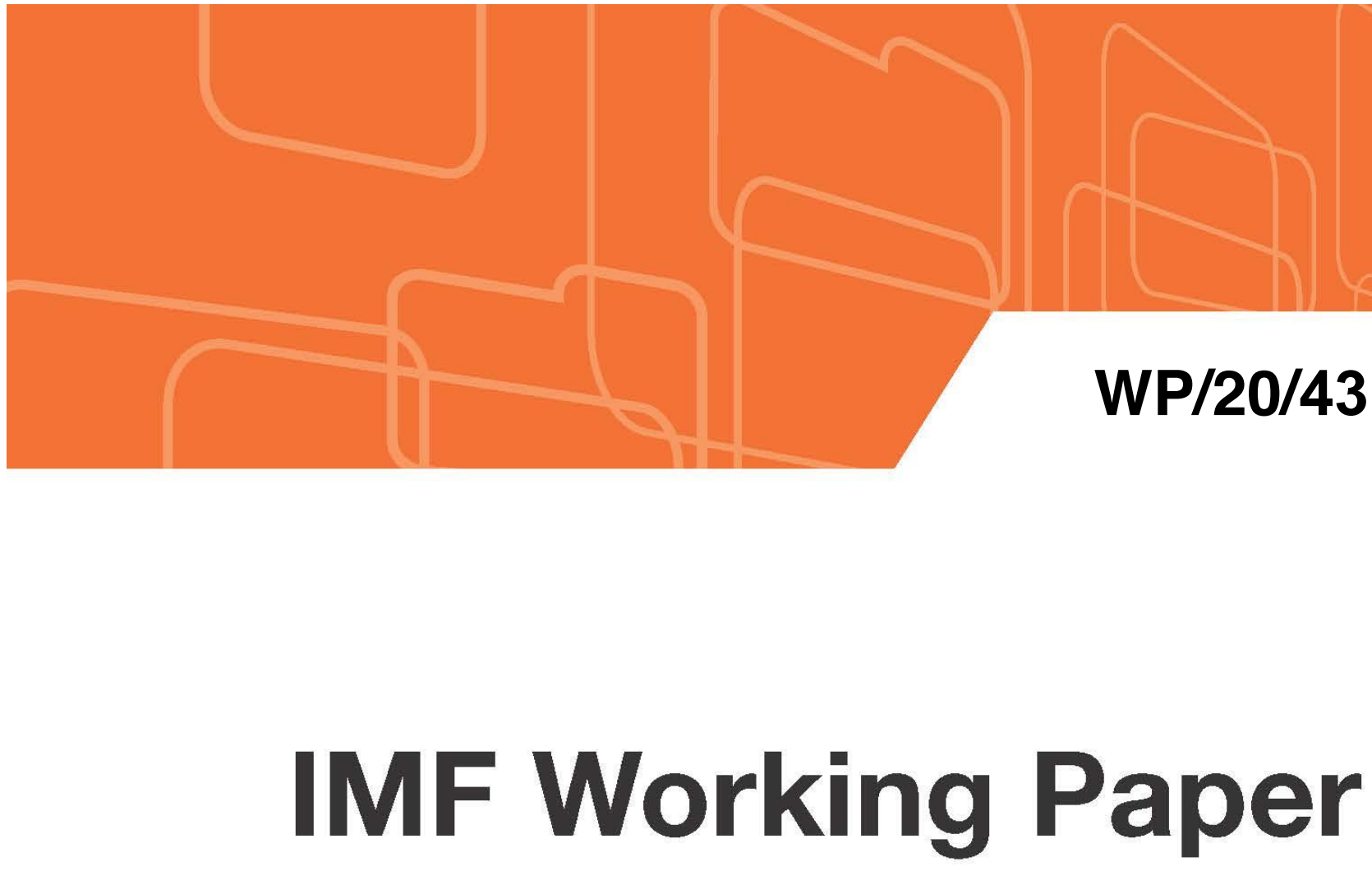

\section{Foreign Demand and Local House Prices: Evidence from the US}

by Anil Ari, Damien Puy, Yu Shi

IMF Working Papers describe research in progress by the author(s) and are published to elicit comments and to encourage debate. The views expressed in IMF Working Papers are those of the author(s) and do not necessarily represent the views of the IMF, its Executive Board, or IMF management. 


\title{
IMF Working Paper
}

Research Department

Foreign Demand and Local House Prices: Evidence from the US

Prepared by Anil Ari, Damien Puy, Yu Shi ${ }^{1}$

Authorized for distribution by Maria Soledad Martinez-Peria

February 2020

IMF Working Papers describe research in progress by the author(s) and are published to elicit comments and to encourage debate. The views expressed in IMF Working Papers are those of the author(s) and do not necessarily represent the views of the IMF, its Executive Board, or IMF management.

\begin{abstract}
We test whether foreign demand matters for local house prices in the US using an identification strategy based on the existence of "home bias abroad" in international real estate markets. Following an extreme political crisis event abroad, a proxy for a strong and exogenous shift in foreign demand, we show that house prices rise disproportionately more in neighbourhoods with a high concentration of population originating from the crisis country. This effect is strong, persistent, and robust to the exclusion of major cities. We also show that areas that were already expensive in the late 1990s have experienced the strongest foreign demand shocks and the biggest drop in affordability between 2000 and 2017. Our findings suggest a non-trivial causal effect of foreign demand shocks on local house prices over the last 20 years, especially in neighbourhoods that were already rather unaffordable for the median household.
\end{abstract}

\section{Author’s E-Mail Address: Aari@imf.org,Dpuy@imf.org, Yshi2@imf.org}

JEL classification: F20, G15, R31

Keywords: House Prices, Housing Affordability, Political Risk, Capital Flows.

\footnotetext{
${ }^{1}$ We thank Emil Verner for a helpful discussion and Maria Soledad Martinez Peria, Deniz Igan and seminar participants at the IMF RES Macro-Financial seminar and the 2nd Annual IMF Macro-Financial Research conference for useful comments. We are also grateful to Huy Quoc Nguyen and Antoine Malfroy-Camine for superb research assistance. The views expressed in this paper are those of the authors and do not represent the views of the IMF, its Executive Board, or IMF management. Author's EMail Address: Aari@imf.org, Dpuy@imf.org, Yshi2@imf.org.
} 


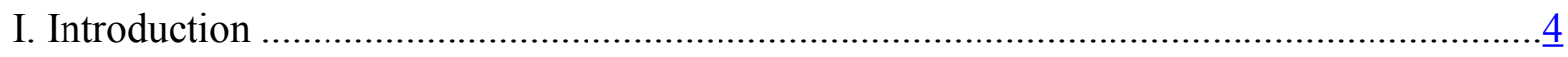

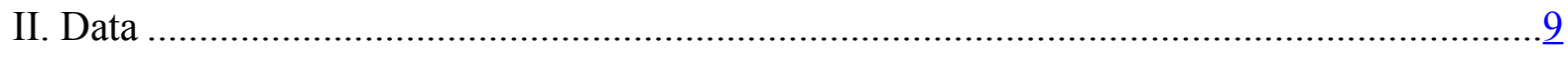

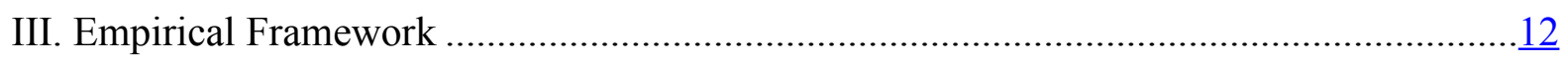

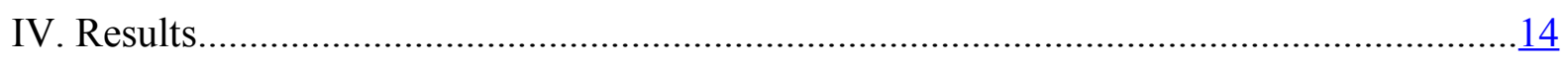

V. Are the Effects Persistent? ..........................................................................................

VI. Foreign Demand and Affordability …………………...............................................

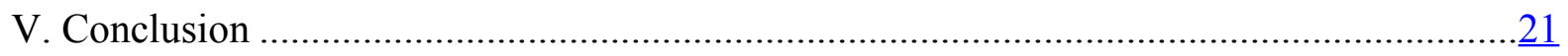

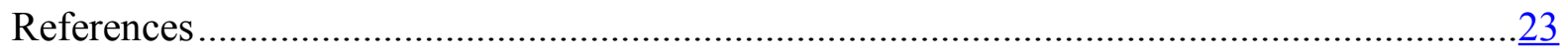

Tables

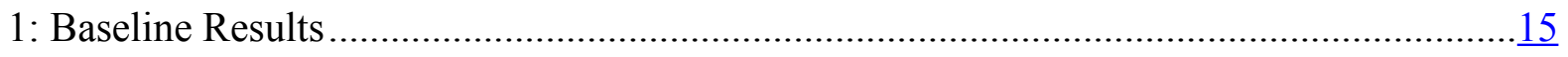

2: Standard Errors Clustered at Different Levels..............................................................16

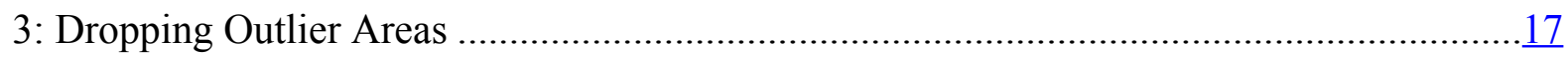

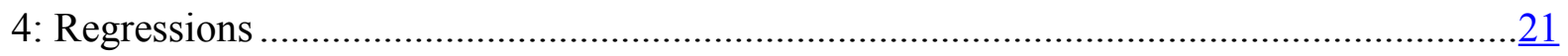

Figures

1: Foreign Exposure across US ZIP codes, selected countries ..............................................11

2: Geographic Concentration of Foreign-born population.................................................

3: Cumulative Effects of Foreign Demand Shocks on Local House Prices .............................18

4: Foreign Demand Shocks and ZIP Code Affordability in 2000 .......................................

5: Foreign Demand Shocks and Change in ZIP Code Affordability (2000-2017) ...................

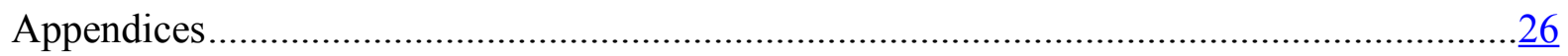




\section{INTRODUCTION}

The recent surge in real estate prices in major cities around the globe has brought back memories of the United States (US) housing boom that ended up in a global financial meltdown. It has also raised concerns about affordability, with millennials being increasingly priced out and at risk of turning into "forever renters". ${ }^{2}$ Lately, the role of foreign demand has also attracted intense public scrutiny. The perception that foreign demand is contributing to inflated local house prices has led to policy interventions in several countries, including differential taxation of house purchases by foreign entities. ${ }^{3}$ Still, robust evidence on the effects of foreign demand on local house prices remains scarce. Standard capital flows data, which could provide direct evidence of such a phenomenon, are not granular enough to isolate real estate transactions. ${ }^{4}$ And even when granular data on property sales are available, the opacity of real estate transactions generally prevents a clean identification of the origin of the buyer. More generally, isolating foreign "push" factors from domestic "pull" factors in capital flow data raises important challenges.

We circumvent these issues by using an identification strategy based on the notion of "home bias abroad" in international real estate markets, which implies that foreign buyers, when investing outside of their home country, concentrate their house purchases in areas where many people originating from their home country reside. The existence of this home bias has been confirmed empirically in various contexts. ${ }^{5}$ Several explanations have also been proposed to rationalize this fact. For instance, common preferences and cultural affinity with the local population might explain such behavior given the possibility of future migration (Bailey et al., 2017). Alternatively, asymmetric information in real estate markets - a phenomenon that has also received ample empirical support - might also be at play. ${ }^{6}$ In that case, the home bias abroad may simply arise to mitigate these asymmetries: foreign buyers may focus their purchases in areas where people from their country of origin are concentrated because they can

\footnotetext{
${ }^{2}$ See, for example, these recent articles on house prices in London, Hong Kong and Los Angeles (Financial Times, $2017 \mathrm{a}$, 2017b, 2018).

${ }^{3}$ See, for instance, Rabanal (2018) for a discussion of stamp duty taxes targeting non-residents in Hong-Kong, or IMF (2018) for a discussion of property-transfer taxes on non-resident homebuyers in Canada.

${ }^{4}$ For example, IFS Balance of Payments or BIS banking flows data. Moreover, the lack of high frequency data on bilateral capital flows and the possibility of transfers through third parties/countries pose challenges for identification using standard capital flows datasets.

${ }^{5}$ See for instance Badarinza, Ramadorai and Shimizu (2019) and other references below.

${ }^{6}$ In the context of real estate markets, Garmaise and Moskowitz (2004), Levitt and Syverson (2008) and Kurlat and Stroebel (2015) document information asymmetries that may relate to difficult-to-observe factors such as imminent changes in neighborhood characteristics. Chinco and Mayer (2016) show that these asymmetries are particularly strong for out-of-town buyers, who are more likely to mistime their purchases, and pay higher property management costs. Agarwal, Sing and Wang (2018) and Miyakawa, Shimizu and Uesugi (2016) reach a similar conclusion with regard to foreign buyers, showing that these asymmetries only decrease after several house purchases in the same country.
} 
benefit from social networks with better "soft" information about local markets or specialized infrastructure (such as real estate agents and property management companies targeting their services to their country of origin).

This paper builds on the existence of this "home bias abroad" to assess the effects of foreign demand on local house prices in the US. More precisely, we conjecture that after an extreme and idiosyncratic political shock in foreign countries - a proxy for a strong and exogenous shift in foreign demand - foreign buyers will invest relatively more in areas with a high exposure to their home country. If so, the difference in house price responses between neighborhoods at different levels of exposure can be interpreted as (indirect) evidence of the effect of foreign demand on local house prices. We test this hypothesis using monthly house prices in 14,993 US ZIP codes between 1996 and 2017.

We proceed in the following manner. We start by constructing a monthly series of foreign country-specific political "shocks" using extreme and idiosyncratic deviations in foreign political ratings compiled by the International Country Risk Guide (ICRG) in 52 emerging and developing economies (EMDEs). ${ }^{7}$ We then measure the exposure of each US neighborhood (at the ZIP code level) to foreign political events using the 2000 US Census data. ${ }^{8}$ Specifically, we proxy for the exposure to a foreign country shock in a given neighborhood using the share of US residents originating from the foreign country that reside in the neighborhood. ${ }^{9}$ Our final measure of ZIP code-level foreign demand shocks is the average foreign political shock across the 52 EMDEs weighted by the neighborhood's exposure to each EMDE. This gives us a monthly time series of foreign demand shocks for each ZIP code in our sample. We assess the static and dynamic impact of those foreign demand shocks on house prices using panel regressions. ${ }^{10}$

Several key results emerge. First, foreign shocks have a strong and significant impact on US housing markets. We estimate that, following a political shock in a foreign country, house prices grow 0.2 percent more after a year in a ZIP code where 1 percent of US residents originating from that country are located (a plausible value in our sample), compared to ZIP codes without any such population. Second, we find that this effect is persistent. The effect of the shock peaks after 20 months and does not reverse in the short run (i.e. in the next two years). Finally, we find that this effect is geographically widespread. In particular, it is not only driven by real estate markets with active foreign buyers, such as Miami, New York and San Francisco.

\footnotetext{
${ }^{7}$ See Appendix Table A1 for a list of countries included in our dataset, and Figure A1 for summary statistics.

${ }^{8}$ In the remainder of the paper, we use the terms "neighborhood" and "ZIP code" interchangeably. We use the 2000 Census since it is the first year for which this measure is available at the ZIP-code level.

${ }^{9}$ We discuss in detail how we construct our exposure measure, as well as potential alternatives. Our key results are insensitive to the way we define foreign exposure, however.

${ }^{10}$ In practice, cumulative effects of foreign demand shocks are computed using local projections (Jordà, 2005).
} 
We also cast light on the link between foreign demand and housing affordability. We highlight two important findings regarding this issue. First, ZIP codes that have experienced more foreign demand shocks between 2000 and 2017 have also experienced the largest decrease in "local" affordability over that period, where we define affordability as the ability of the median household (in the ZIP code) to buy (or rent) the median property in that area. This suggests that foreign demand has played a role in the historical drop in US housing affordability that we observe in the data. ${ }^{11}$ Second, we also show that the strong correlation between foreign demand shocks and (change in) local affordability is mainly driven by neighborhoods that were already rather unaffordable for locals in the late 1990s. This, in turn, seems to be driven by the fact that areas that were already expensive at the beginning of our sample have also experienced more foreign demand shocks than the more affordable neighborhoods.

A key identification assumption of our framework is that political shocks in a given foreign country do not correlate with other shocks that disproportionately affect house prices in ZIP codes with high exposure to the same country. While this assumption is hard to satisfy with only one foreign country, our use of political risk and foreign exposure measures for 52 EMDEs helps to ensure that any bilateral co-movement between the US and a given country is unlikely to bias our estimates. We also discuss three other potential challenges to our identification. First, there may be geographical spillovers in housing demand. Since such spillovers would bias our estimates downward, our results can be interpreted as a lower bound for the effect of foreign demand shocks on local house prices. Second, foreign political risk shocks could be driven by a common factor, such as a global financial shock. If this common factor also affects house prices differentially in areas that are attractive to foreign-born residents, our results would be biased. For example, areas that are more integrated into international markets could be disproportionately affected by global financial shocks. To mitigate this concern, we first purge the raw political risk indexes from their socio-economic conditions and investment profile components, which move closely with international borrowing costs and more generally with global economic events that are linked to US conditions. We also interact the total foreign exposure of each ZIP code to all 52 EMDEs with the VIX volatility index, which is a proxy for a common factor. Our results are robust to controlling for this interaction. Third and more generally, areas with different concentrations of foreign-born population may have different local business cycles, which may be directly or indirectly related to political risk abroad through channels other than demand for housing from

\footnotetext{
${ }^{11}$ The reduction in housing affordability in the US has been widely documented (see Dumont (2019) and references therein). In practice, we measure affordability for locals both in terms of buying and renting property using (i) the median home value and (ii) the median gross rent in a ZIP code, both normalized by the median household income in the same ZIP code.
} 
foreign buyers. Nevertheless, our results remain significant after controlling for potentially different local business cycles in areas with different shares of foreign-born population. ${ }^{12}$

This paper naturally relates to a large literature on the determinants of house prices in the US. ${ }^{13}$ Our identification strategy, based on the notion of "home bias abroad" in real estate purchases, relates to a larger literature on home bias in asset holdings. ${ }^{14}$ Recently, Badarinza, Ramadorai and Shimizu (2019) provide evidence for substantial home bias in real estate markets. Using data from 70 countries, they find that overseas buyers have a strong tendency to transact with sellers from their country of origin and are willing to pay a premium on their purchases to do so. Our paper is also closely related to Badarinza and Ramadorai (2018), who analyze the impact of foreign buyers on house prices in London. Using large datasets of housing transactions in London and a similar identification strategy, they find that foreign risk strongly affects London house prices and argue that both safe haven effects and immigration drive those results. Broadly speaking, our findings confirm the importance of foreign investors in local house price dynamics, as well as the advantages of this identification strategy in capturing such effects.

Our approach differs in two ways, however. First, we extend the scope of the analysis. Our dataset covers 14,993 ZIP codes across the United States, which accounts for 95\% of the total US housing stock by value, and $85 \%$ of total US population. Going beyond a single city allows us to check the robustness of our results to controlling for rural-urban differences and potentially different local business cycles in areas with high and low share of foreign-born population. We also explore a novel and important question: the impact of foreign demand on local housing affordability, rather than house prices per se. To avoid possible reverse causality from within-US variation in house prices (or more generally US business cycles) to foreign political risk, we also adopt a different measure of foreign exposure - namely the geographic concentration of foreign-born residents. ${ }^{15}$ This differs from Badarinza and Ramadorai (2018), where the exposure of a locality to a foreign country is measured using the share of local population originating from that country. Both measures, in principle, could capture important

\footnotetext{
12 Specifically, we divide ZIP codes into groups of high, medium and low share of foreign-born population, and interact these groups with time fixed effects. Our results are again unaffected.

${ }^{13}$ See e.g. Case and Shiller (1990), Peek and Wilcox (1991), Lamont and Stein (1999), Gyourko, Mayer and Sinai (2013), Mian and Sufi (2009) and Shiller (2007), among others.

${ }^{14}$ See e.g. French and Poterba (1991), Coval and Moskowitz (1999), Huberman (2001), Ahearne, Griever and Warnock (2004), Van Nieuwerburgh and Veldkamp (2009), Coeurdacier and Rey (2013).

${ }^{15}$ More precisely, our proxy for the exposure of a neighborhood to a foreign country is the ratio of neighborhood residents born in that foreign country to all US residents originating from the same country.
} 
determinants of foreign demand. ${ }^{16}$ However, focusing on geographic concentration avoids giving excessive weight to countries where the political situation might be affected by events in the US. ${ }^{17}$ These are primarily countries that are (i) geographically close to the US (e.g. Mexico) or (ii) have a large population and the US as a major trading partner (e.g. China and India). Importantly however, we find that our results are robust to changes in the way we measure foreign exposure at the ZIP code level. ${ }^{18}$

The empirical relationship we identify between foreign political risk shocks and local house prices in the US could be driven by several alternative transmission channels. First, capital inflows from abroad may contribute to house price growth. Reinhart and Reinhart (2008), Aizenman and Jinjarak (2009) and Sá and Wieladek (2015) find a positive association between capital inflows and house prices, while Sá, Towbin and Wieladek (2014) show that this relationship is strongest in countries with more developed mortgage markets. ${ }^{19}$ Second, political risk shocks abroad may lead to greater migration from the source countries. In this respect, our use of the country of origin of the local population to determine exposure to foreign demand shocks is close to the use of historical settlement patterns to predict the geographic distribution of future migrants (see e.g. Cortes, 2008; Sá 2015; Card and Di Nardo, 2000; Card, 2001; Saiz and Wachter, 2011). However, the existing literature is ambiguous about the effects of immigration on house prices, as it may lead to out-migration of the native population to different regions. ${ }^{20}$ Third, our findings may capture the response of the local diaspora population to political risk shocks in their country of origin. For example, individuals in the diaspora may reduce their remittances and invest in local real estate instead.

Finally, our paper is closely related to a recent literature on the impact of out-of-town buyers on local housing market conditions. Suher (2016) exploits a change in New York City's property tax treatment of non-resident house owners to show that demand from abroad has a significant impact on house prices in highly desirable neighborhoods. Our findings provide evidence that demand shocks from abroad may impact house prices across the US, including

\footnotetext{
${ }^{16}$ For example, specialized infrastructure that alleviates information asymmetries might be primarily reflected in the geographic concentration measure, while the size relative to local population might be more important for perceived cultural affinity. The strength of social networks, on the other hand, might be captured equally well by both measures.

${ }^{17}$ The focus on a single city in a small open economy alleviates this problem in Badarinza and Ramadorai (2018).

${ }^{18}$ Appendix B shows that our key results are robust - and in fact stronger - when using the same foreign exposure measure as Badarinza and Ramadorai (2018).

${ }^{19}$ In a similar vein, Cesa-Bianchi, Cespedes and Rebucci (2015) find that global liquidity shocks have a positive impact on house prices. In contrast, Jinjarak and Sheffrin (2011) find little evidence of a causal relationship between current account deficits and real estate prices.

${ }^{20}$ Particularly, Saiz (2007), Degen and Fischer (2017) and Gonzalez and Ortega (2013) find a positive association between immigration and house prices, while Saiz (2003), Saiz and Wachter (2011) and Sá (2015) reach the opposite conclusion. The latter two studies, along with Borjas, Freeman, and Katz (1992), also provide evidence for out-migration of natives to different regions in response to immigration.
} 
areas outside large metropolitan centers. Favilukis and Van Nieuwerburgh (2017) use a spatial equilibrium model to quantify the effects of foreign house buyers on the local population. They show that demand shocks similar to those we identify may have adverse welfare and distributional effects.

The remainder of this paper is organized as follows. Section II presents the data used in the paper and provides some stylized facts regarding the geographical distribution of foreigners in the US. Section III presents the empirical framework and discusses the main identification challenges. Section IV presents the key results from our empirical analysis. Section V and VI are dedicated to the persistence of the effects of foreign demand shocks and their impact on local housing affordability, respectively. Section VII concludes.

\section{DATA}

\section{A. Sources and Construction}

\section{House prices}

House price data is taken from the Zillow Home Value Index (ZHVI) which is available at a monthly frequency at the US ZIP code level. The dataset we use covers 14,993 ZIP codes between 1996 and 2017. For each month and each ZIP code, the ZHVI reports the median of actual and estimated market values of all homes within the area. From a methodological perspective, the ZHVI suffers from less bias in small geographical subdivisions than the CaseShiller index, which relies on limited repeated sales data. ${ }^{21}$ It is also very comprehensive, covering $95 \%$ of the total housing stock by value (and $85 \%$ of total US population).

\section{Foreign political shocks}

Foreign political shocks for each of the 52 source countries are identified in a two-step procedure (See Appendix Table A1 for a list of countries). We first collect the Political Risk Index (PRI) from the ICRG as a proxy for country-specific political uncertainty, which rates countries, every month, on twelve dimensions, namely (i) Government Stability (12 points), (ii) Socioeconomic Conditions (12 points), (iii) Investment Profile (12 points), (iv) Internal Conflict (12 points), (v) External Conflict (12 points), (vi) Corruption (6 points), (vii) Military in Politics (6 points), (viii) Religious Tensions (6 points), (iv) Law and Order (6 points), (x) Ethnic Tensions (6 points), (xi) Democratic Accountability (6 points) and (xii) Bureaucracy Quality (4 points). In line with the literature, we rely on the ICRG rating because of its ability

\footnotetext{
${ }^{21}$ See https://www.zillow.com/research/zhvi-methodology/ for further details on the methodology behind ZHVI and https://wp.zillowstatic.com/3/ZHVI-InfoSheet-04ed2b.pdf for a comparison with the Case-Shiller Index.
} 
to capture changes in the quality of legal and political institutions over time for each country, rather than cross-sectional differences in institutional quality (Glaeser et al., 2004). ${ }^{22}$

To avoid capturing movements in political risk that are endogenous to the global financial cycle - and therefore to the US, we first purge the raw indexes from their socio-economic conditions and investment profile sub-indexes, which move closely with international borrowing costs and more generally with global economic events that are linked to US conditions. We call this new version Political Risk Index Purged (PRIP). Next, we transform the purged version of the index into a binary variable. Our final (monthly) measure of foreign political shocks takes the value of one in month $t$ in country $c$ if the value of the index is above the $95^{\text {th }}$ percentile of the (country-specific) series. Formally, this can be written as:

$$
\text { Pol }_{c, t}=1 \text { if } P R I P_{c, t}>p(95)
$$

As a result, our foreign political shocks series capture strong and idiosyncratic political shocks in source countries. The final sample of source countries is provided in the Appendix, along with an example illustrating the difference between raw, purged and binary versions of political risk measures. ${ }^{23}$

\section{Foreign exposure measures}

We measure exposure to foreign shocks in each ZIP code using data on the foreign-born population from the same 52 EMDEs according to the 2000 US Census. Denoting $F B_{i, c}$ as the number of residents in ZIP code $i$ born in country $c$, we compute our Foreign Exposure index $F_{i, c}$ as follows:

$$
F_{i, c}=F B_{i, c} / F B_{U S A, c}
$$

where $F B_{U S A, C}$ denotes the total number of US residents originating from country $c$. Our ratio therefore computes the share of residents from any given country in any given ZIP code as a ratio of all US residents from that same country. To create our final ZIP code specific foreign demand shock time series $\left(F D_{i, t}\right)$, we simply interact, every month, our Foreign Political Risk dummy $\left(\right.$ Pol $\left._{c, t}\right)$ with our Foreign Exposure index $\left(F_{i, c}\right)$, thereby weighting the various political shocks from the 52 source countries according to the geographical concentration of foreigners in the ZIP code. Formally, we can write this as:

$$
F D_{i, t}=\sum_{c} F_{i, c} * \Delta P o l_{c, t}
$$

\footnotetext{
${ }^{22}$ See Badarinza and Ramadorai (2018), and references therein, for a discussion of the benefits of the ICRG ratings, and examples of their use in the international finance literature.

${ }^{23}$ See Figure A2 and Figure A3.
} 


\section{B. Stylized Facts}

We highlight two key stylized facts regarding the Foreign Exposure index. First, the distribution of foreigners varies significantly across countries, implying that not all nationalities cluster in the same ZIP codes. This fact is illustrated in Figure 1, which plots foreign exposure indexes of all US ZIP codes for Mexico, the Philippines, China and India; the four countries with the highest (aggregate) foreign-born population in the US in 2000 according to the US Census (See Figure A.1, in Appendix). Another important finding is that the foreign-born population within the US does not only live in major cities and very urban/populated areas. Although major cities contain neighbourhoods with a high concentration of foreign-born population, especially on the coasts, Figure 2 shows that the foreign-born population is geographically dispersed across the US, including in rural areas. ${ }^{24}$ This suggests that the effects we identify do not depend only on a rural-urban divide; a finding we confirm in Section 3.

Figure 1: Foreign exposure across US ZIP codes, selected countries
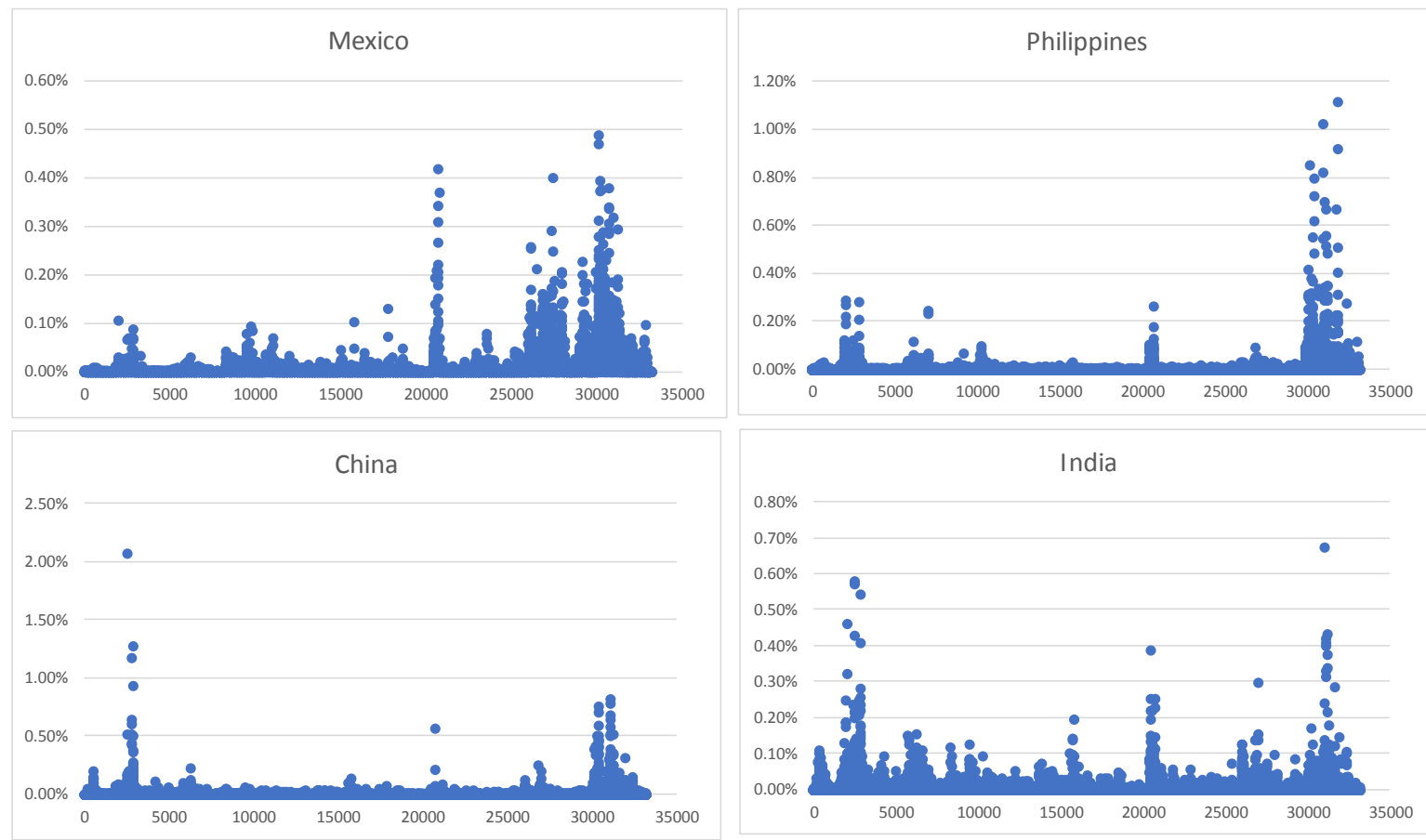

Notes: Ratios on the $y$ axis report the number of foreign-born from country $c$ in each ZIP code, divided by the total amount of foreign born from that same country in the US. Each ZIP code is represented on the $x$ axis in ascending numerical order (i.e. with the first ZIP Code ordered first). The sample covers more than 33.000 US ZIP codes ranging from ZCTA 00601 to ZCTA5 99950.

\footnotetext{
${ }^{24}$ Figure 2 maps the different percentiles of the distribution of the foreign exposure across US ZIP codes as of 2000. For instance, areas in bright red fall between the $75^{\text {th }}$ and $90^{\text {th }}$ percentiles. Since foreign exposures are country specific at the ZIP code level (i.e. each ZIP code is exposed to many countries), we use an average across countries.
} 
Figure 2: Geographic concentration of foreign-born population

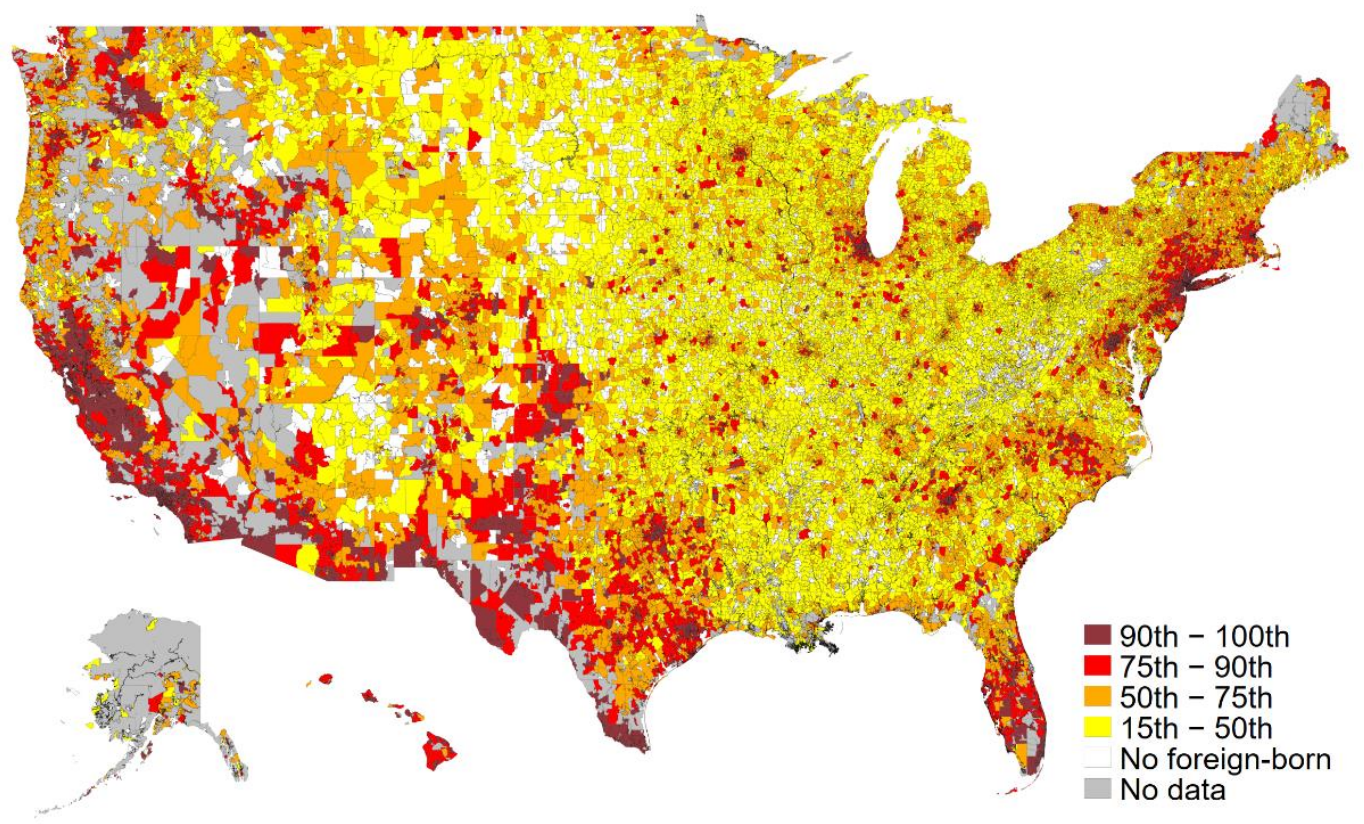

\section{EMPIRICAL FRAMEWORK}

We present below the specification for our baseline empirical analysis, the purpose of which is to identify the significance of foreign demand shocks on local house prices. For the sake of clarity, we first focus on a static specification and use it to discuss the main identification assumptions and challenges and perform robustness tests. The local projection specification which is used to further explore the cumulative dynamic effects - is discussed later.

\section{Specifications}

We start by estimating the following specification:

$$
\Delta \ln (h p)_{i t}=\alpha_{0}+\sum_{s=1}^{L} \alpha_{s} \Delta \ln (h p)_{i, t-s}+\sum_{s=1}^{l} \beta_{s} F D_{i, t-s}+\eta_{i}+\psi_{t}+\epsilon_{i, t}
$$

where $\Delta \ln (h p)_{i t}$ denotes the $\log$ difference in house prices in ZIP code $i$ in month $t, F D_{i, t-s}$ is the s-month lag of our proxy for foreign demand shocks to ZIP code $i$, and $\eta_{i}$ and $\psi_{t}$ are vectors of ZIP code and time fixed effects, respectively. Parameters are estimated using OLS and standard errors are clustered at the ZIP code level. 


\section{Identification Assumption and Challenges}

The identification of (1) hinges on the assumption that political shocks to country $c$ do not correlate with other shocks that disproportionately affect house prices in ZIP codes with high exposure to country $c$. We identify three potential challenges that might violate this identification assumption. First, demand shocks in a ZIP code could spill over to nearby locations, thus contaminating the differences across ZIP codes. However, such spillovers would introduce a downward bias in our coefficient estimates from specification (1). Our results in this case can be interpreted as a lower bound for the actual effect of foreign demand shocks on local house prices.

Second, foreign political risk shocks in different countries could be driven by a common (or world) factor, such as a major financial crisis, which also affects house prices in the US differentially. For example, suppose that global financial shocks raise political risk in EMDEs. Suppose also that areas of the US which are more exposed to these global financial shocks happen to attract more foreign-born residents (leading to high $F_{i, c}$ ). Positive and significant estimates for coefficient $\beta$ in specification (1) could then be due to these shocks instead of foreign demand driven by idiosyncratic foreign political risk shocks. To mitigate this concern, we control for the interaction of the VIX volatility index - as a proxy for the common shock to all countries - and the sum of Foreign Exposure of ZIP code $i, F_{i, c}$, across the 52 EMDEs:

$\Delta \ln (h p)_{i t}=\alpha_{0}+\sum_{s=1}^{L} \alpha_{s} \Delta \ln (h p)_{i, t-s}+\sum_{s=1}^{l} \beta_{s} F D_{i, t-s}+\gamma V I X_{t-1} \sum_{c} F_{i, c}+\eta_{i}+\psi_{t}+\epsilon_{i, t}$

A third concern is that, more generally, neighborhoods with a higher share of foreign-born residents might have different local business cycles to begin with. For instance, local economic conditions in regions (or ZIP codes) with a higher share of immigrants - such as parts of New York and San Francisco - might be more correlated with the global business cycle, so that we face a similar problem as in the second identification challenge; or house prices in these cities could be more correlated with the US housing cycle, which may in turn comove with foreign political risk. In either case, our baseline estimates would capture effects that are not directly related to demand from foreign buyers, or even the presence of foreign-born residents.

We deal with this last challenge in two ways. We first construct a new measure, the immigrant ratio $\left(I M R_{i}\right)$, defined as the ratio of total foreigners in ZIP code $i$ over the total population in the ZIP code. We then control for the interaction of the immigrant ratio and the first lag of the VIX volatility index in Specification (3). ${ }^{25}$

\footnotetext{
${ }^{25}$ When they are not interacted, the immigrant ratio $I M R_{i}$ and VIX index $V I X_{t-1}$ are absorbed by the ZIP code and time fixed effects, respectively.
} 
$\Delta \ln (h p)_{i t}=\alpha_{0}+\sum_{s=1}^{L} \alpha_{s} \Delta \ln (h p)_{i, t-s}+\sum_{s=1}^{l} \beta_{s} F D_{i, t-s}+\gamma V I X_{t-1} \times I M R_{i}+\eta_{i}+\psi_{t}+\epsilon_{i, t}(3)$

In Specification (4), we account for the possibility that the immigrant concentration in regions might matter in a nonlinear way by dividing ZIP codes into three equal groups - low (L), medium $(\mathrm{M})$, and high $(\mathrm{H})$ immigrant concentration - based on the IMR measure. We then control for group-specific time fixed effects to allow the different ZIP codes to have potentially different local housing market cycles.

$$
\Delta \ln (h p)_{i t}=\alpha_{0}+\sum_{s=1}^{L} \alpha_{s} \Delta \ln (h p)_{i, t-s}+\sum_{s=1}^{l} \beta_{s} F D_{i, t-s}+\eta_{i}+\sum_{k=L, M, H} \psi_{k t}+\epsilon_{i, t}
$$

Finally, in Section IV.B, we also report results after excluding cities where most of the foreignborn population in the US is concentrated.

\section{Results}

\section{A. Baseline}

Table 1 summarizes the baseline results based on monthly data from 14,993 ZIP codes over 1996-2017. Column (1a) reports estimates using Specification (1) with two-month lags of house prices and three-month lags of foreign demand shocks. The estimates indicate that foreign political risk shocks lead to a significant increase in house prices in areas that are more exposed to the source countries. The significant effect is persistent for up to three lags. Column (1b) includes two additional months of lags of house prices, and the effect of the first two lags of foreign demand shocks on local house prices remain positive and significant. Column (2) reports the results using Specification (2). The coefficient of the first lag of the VIX volatility index $\left(V I X_{t-1}\right)$ interacted with aggregate exposure to foreign countries at the ZIP code is negative and significant, indicating that higher global volatility reduces house prices disproportionately in areas with a higher foreign exposure. Adding this control variable unsurprisingly attenuates the estimated impact of foreign political risks on local house prices. Nevertheless, the second lag of our foreign demand measure remains positive and significant at $99 \%$ confidence level. Column (3) reports the results from Specification (3), where VIX $X_{t-1}$ is interacted with the immigrant ratio $I M R_{i}$ instead of aggregate exposure. As in column (2), the interaction term is negative and significant, while the second lag of our foreign demand measure remains positive and significant. Finally, in Column (4), we report the estimates based on Specification (4), which takes into account possible heterogeneity in local business (or housing market) cycles. The results indicate that the coefficient for foreign demand at 2 months lag remains positive and significant at $99 \%$ confidence level. 
Table 1: Baseline results

\begin{tabular}{|c|c|c|c|c|c|}
\hline & \multicolumn{5}{|c|}{$\Delta \ln (h p)_{i, t}$} \\
\hline & (1a) & (1b) & (2) & (3) & (4) \\
\hline \multirow[t]{2}{*}{$F D_{i, t-1}$} & $0.0214 * * *$ & $0.0124 * * *$ & 0.00184 & -0.00191 & -0.00367 \\
\hline & $(0.00624)$ & $(0.00473)$ & $(0.00444)$ & $(0.00439)$ & $(0.00456)$ \\
\hline \multirow[t]{2}{*}{$F D_{i, t-2}$} & $0.0173 * * *$ & $0.0186^{* * *}$ & $0.0196 * * *$ & $0.0197 * * *$ & $0.0173 * * *$ \\
\hline & $(0.00623)$ & $(0.00548)$ & $(0.0053)$ & $(0.0054)$ & $(0.0054)$ \\
\hline \multirow{2}{*}{$F D_{i, t-3}$} & $0.0136^{* *}$ & 0.00465 & 0.00198 & 0.000881 & -0.00619 \\
\hline & $(0.00663)$ & $(0.00499)$ & $(0.00474)$ & $(0.00476)$ & $(0.00483)$ \\
\hline \multirow{2}{*}{$\sum_{c} F_{i, c} \times V I X_{t-1}$} & & & $-0.0247 * * *$ & & \\
\hline & & & $(0.00204)$ & & \\
\hline$I M R_{i} \times V I X_{t-1}$ & & & & $\begin{array}{c}-0.00409 * * * \\
(0.000123)\end{array}$ & \\
\hline Constant & $\begin{array}{c}0.000185 * * * \\
(5.79 \mathrm{E}-05)\end{array}$ & $\begin{array}{c}0.000333 * * * \\
(4.49 \mathrm{E}-05)\end{array}$ & $\begin{array}{c}0.000585 * * * \\
(4.91 \mathrm{E}-05)\end{array}$ & $\begin{array}{c}0.00119 * * * \\
(5.19 \mathrm{E}-05)\end{array}$ & $\begin{array}{c}0.000417 * * * \\
(3.84 \mathrm{E}-05)\end{array}$ \\
\hline No. of observations & $3,407,334$ & $3,376,332$ & $3,376,332$ & $3,376,332$ & $3,376,332$ \\
\hline R-squared & 0.714 & 0.775 & 0.775 & 0.775 & 0.776 \\
\hline No. of ZIP codes & 14,993 & 14,993 & 14,993 & 14,993 & 14,993 \\
\hline $\begin{array}{l}\text { No. of lags of } \\
\Delta \ln (h p)\end{array}$ & 2 & 4 & 4 & 4 & 4 \\
\hline Time FE & Yes & Yes & Yes & Yes & No \\
\hline ZIP code FE & Yes & Yes & Yes & Yes & Yes \\
\hline $\mathrm{L}, \mathrm{M}, \mathrm{H} \times$ Time $\mathrm{FE}$ & No & No & No & No & Yes \\
\hline
\end{tabular}

Notes: Robust standard errors in parentheses. ${ }^{* * *} p<0.01,{ }^{* *} p<0.05,{ }^{*} p<0.1 . L, M$ and $H$ refer to fixed effects that vary by low $(L)$, medium $(M)$, and high $(H)$ immigrant concentration - based on the IMR measure.

\section{B. Robustness}

To ensure the validity of our baseline results, we conduct several robustness tests. First, we repeat the baseline estimation in Column (1b) of Table 1 but cluster the standard errors at the city, county, MSA, and state levels instead of at the ZIP code level. This robustness test could deal with potentially correlated economic shocks within a region. Table 2 reports the results of the first robustness test. Compared to Table 1, the second lag of the foreign demand shock remains significant even if we cluster the standard errors at the MSA level. The significance disappears when clustering the standard errors at the state level, possibly due to the lack of significant variation in foreign exposure across different states. 
Second, to make sure that our significant results are not driven by a few outliers or cities, we drop cities which have traditionally been popular among foreign buyers or the ones that are likely to be outliers. We consider outliers cities containing ZIP codes that experienced the top and bottom 1 percentile of weighted average political shocks. These are Arlington, Glendale, Hialeah, Los Angeles, New York, North Miami, and Sterling Heights. ${ }^{26}$ We also drop the following metropolitan areas which are popular among foreign buyers: Miami-Fort Lauderdale FL, Seattle WA, San Francisco CA, Los Angeles-Long Beach-Anaheim CA. Table 3 summarizes the resulting estimates. Compared to Table 1, we find that the effects of foreign demand shocks are generally stronger.

Table 2: Standard Errors Clustered at Different Levels

\begin{tabular}{lcccc}
\hline & & \multicolumn{2}{c}{$\Delta \ln (h p)_{i, t}$} & $(4)$ \\
\hline Cluster & City & County & MSA & State \\
\hline & & & & \\
$F D_{i, t-1}$ & 0.0124 & 0.0124 & 0.0124 & 0.0124 \\
& $(0.00814)$ & $(0.00783)$ & $(0.00961)$ & $(0.00945)$ \\
$F D_{i, t-2}$ & $0.0186^{* *}$ & $0.0186^{*}$ & $0.0186^{*}$ & 0.0186 \\
& $(0.00950)$ & $(0.0105)$ & $(0.0112)$ & $(0.0139)$ \\
$F D_{i, t-3}$ & 0.00465 & 0.00465 & 0.00465 & 0.00465 \\
& $(0.00573)$ & $(0.00764)$ & $(0.00555)$ & $(0.00863)$ \\
& & & & \\
\hline No. of observations & $3,376,332$ & $3,376,332$ & $3,376,332$ & $3,376,332$ \\
R-squared & 0.775 & 0.775 & 0.775 & 0.775 \\
No. of Clusters & 8,150 & 1,229 & 730 & 51 \\
No. of lags of $\Delta \ln (h p)$ & 4 & 4 & 4 & 4 \\
Time FE & Yes & Yes & Yes & Yes \\
ZIP code FE & Yes & Yes & Yes & Yes \\
\hline
\end{tabular}

Notes: Clustered standard errors in parentheses. ${ }^{* * *} p<0.01,{ }^{* *} p<0.05,{ }^{*} p<0.1$

\footnotetext{
${ }^{26}$ The geographical boundary of cities follows the definition in the Zillow database.
} 
Table 3: Dropping Outlier Areas

\begin{tabular}{|c|c|c|}
\hline & \multicolumn{2}{|c|}{$\Delta \ln (h p)_{i, t}$} \\
\hline & $(1)$ & $(2)$ \\
\hline Cities dropped & $\begin{array}{c}\text { Outliers (in } \\
\text { terms of } \\
\text { shocks) }\end{array}$ & $\begin{array}{l}\text { Popular among } \\
\text { foreigners }\end{array}$ \\
\hline$F D_{i, t-1}$ & $\begin{array}{c}0.0231 * * * \\
(0.00534)\end{array}$ & $\begin{array}{c}0.0322 * * * \\
(0.00562)\end{array}$ \\
\hline$F D_{i, t-2}$ & $\begin{array}{c}0.00825 \\
(0.00633)\end{array}$ & $\begin{array}{c}0.0198 * * * \\
(0.00671)\end{array}$ \\
\hline$F D_{i, t-3}$ & $\begin{array}{c}0.0307 * * * \\
(0.00519)\end{array}$ & $\begin{array}{c}0.0221 * * * \\
(0.00566)\end{array}$ \\
\hline No. of observations & $3,099,340$ & $3,329,853$ \\
\hline R-squared & 0.770 & 0.774 \\
\hline No. of Clusters & 13,802 & 14,760 \\
\hline No. of lags of $\Delta \ln (h p)$ & 4 & 4 \\
\hline Time FE & Yes & Yes \\
\hline ZIP code FE & Yes & Yes \\
\hline
\end{tabular}

Notes: Standard errors in parentheses clustered at the ZIP code level. ${ }^{* * *} p<0.01,{ }^{* *} p<0.05,{ }^{*} p<0.1$

Finally, we test whether our results are driven by an outlier country by estimating Specification (1)-(4) after dropping each country in the 52 EMDEs one by one. The coefficients from these new estimations are not statistically different from those reported in Table 1, suggesting that there is no single country that is crucial to our findings. ${ }^{27}$

\section{ARE THE EFFECTS PERSISTENT?}

Are the effects of foreign demand shocks temporary or long-lasting? To explore this question, we turn to a dynamic framework and estimate the (cumulative) response of foreign demand shocks on local house prices using Jordà's (2005) local projection method. This choice is mainly driven by the uncertainty surrounding the timing, strength and linearity of the response in house prices to extreme events abroad. In this context, a flexible estimation method that is more robust to misspecification than a typical VARs is desirable. In practice, we estimate the following specification, which is a direct extension of Specification (4):

\footnotetext{
${ }^{27}$ The results after dropping individual countries are not reported in the interest of brevity, but are available upon request.
} 


$$
\Delta \ln (h p)_{i, t, t+h}=\partial_{h}+\sum_{s=1}^{l} \alpha_{s}^{h} \Delta \ln (h p)_{i, t-s}+\sum_{s=1}^{l} \beta_{s}^{h} F D_{i, t-s}+\eta_{i, h}+\sum_{k=L, M, H} \psi_{k, t}^{h}+\varepsilon_{i, h}^{t}
$$

where $h$ denotes the horizon of projection and $\Delta \ln (h p)_{i, t, t+h}$ reports the cumulative change (in $\%$ ) in the house price level between month $t$ and $t+h$ in ZIP-code $i$. All other variables have the same definitions as before. We use 4 lags for all variables (i.e. $l=4$ ), but results are not sensitive to changes in the number of lags. Since the error term in the local projection framework follows a moving average process of order $h-1$ by construction, standard errors are always corrected for autocorrelation. Finally, the inclusion of $\psi_{k, t}^{h}$ which allows for different types of neighborhoods to have potentially different local business cycles, implies that we are using the most conservative approach to estimate cumulative effects.

Results are reported in Figure 3, which plots $\beta_{s}^{h}$ at different horizons, along with $90 \%$ and $95 \%$ confidence intervals. Qualitatively, we find that the effects of foreign demand shocks we identify in the previous section are increasing and persistent. Moreover, the effects follow a non-linear path: They peak after one year before declining for a few months, and then rising again. The effects stabilize at around $20 \%$ after 20 months. Taken at face value, the coefficient size implies that, following a political shock in country $c$, house prices in a ZIP-code where all foreigners from country $c$ reside would rise $20 \%$ more than a ZIP code without any foreigners. Using a more realistic value of $1 \%$ of US residents originating from country $c$, a plausible amount in our sample, would imply $0.2 \%$ more growth (after a year) in the ZIP code, compared to ZIP codes without any such population.

Figure 3: Cumulative Effects of Foreign Demand Shocks on Local House Prices

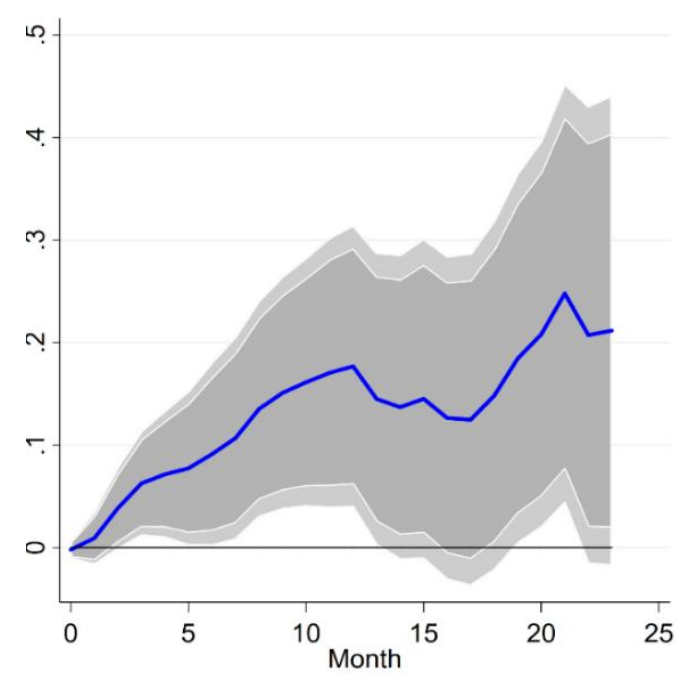

Notes: The vertical axis shows the cumulative growth of ZIP code-level house prices following a shock. Shaded areas report $90 \%$ and $95 \%$ confidence intervals, respectively. 


\section{FOREIGN SHOCKS AND AFFORDABILITY}

Is foreign demand really making US neighborhoods less affordable? The recent surge in house prices in major US cities has raised concerns about affordability. This concern is especially vivid among young people who are increasingly feeling priced out of the housing market.

We highlight two important findings regarding this question. First, over the last 20 years, foreign demand shocks have been historically stronger in US neighborhoods that were already hard to afford in the late 1990s. This finding is summarized in Figure 4, which plots the intensity of foreign shocks in ZIP code $i$ - measured by the sum of our proxy for foreign demand shocks between 2000 and 2017 - against the expensiveness or unaffordability of ZIP code $i$ before shocks happened (i.e. in 2000). We define "expensiveness" as (i) the median home value divided by the median household income in ZIP code $i$ (left panel) and (ii) the median gross rent divided by the median household income in ZIP code $i$ (right panel). Overall, we find that ZIP codes in which it was already hard to buy (or rent) for the median household have also experienced the largest foreign demand shocks over the last 20 years.

Second, we find that the intensity of foreign demand shocks is strongly (positively) correlated with the change in expensiveness over the sample period. In other words, ZIP-codes that have experienced more foreign demand shocks between 2000 and 2017 have also seen the biggest decrease in affordability (or rise in expensiveness), measured using both the costs of buying or renting (Figure 6, upper panels). Consistent with Figure 4, Figure 5 also shows that the most unaffordable neighborhoods in 2000 - captured by the 5\% least affordable ZIP codes in 2000 - are concentrated in the upper right corner, suggesting that the strongest reduction in affordability happened in areas that were expensive to begin with. This finding is confirmed in a more formal regression analysis where we do not use an arbitrary threshold at 5\% (See Table 4).

Taken together, our results suggest that foreign demand shocks have impacted local house prices everywhere in the US - not only in the major US cities - and contributed to the general drop in US housing affordability between 2000 and 2017. They also indicate that foreign demand shocks have, on average, had a stronger impact in areas where it was already hard to buy (or rent) for the median US household. 
Figure 4: Foreign Demand Shocks and ZIP Code Affordability in 2000.
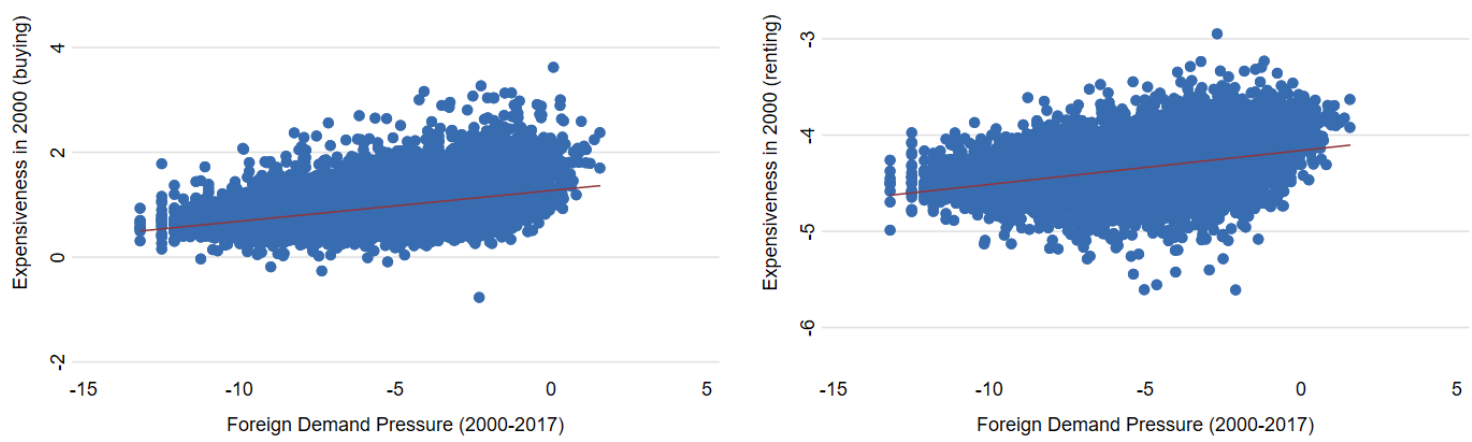

Notes: All variables are reported in logarithmic scale.

Figure 5: Foreign Demand Shocks and Change in ZIP code Affordability (2000- 2017)
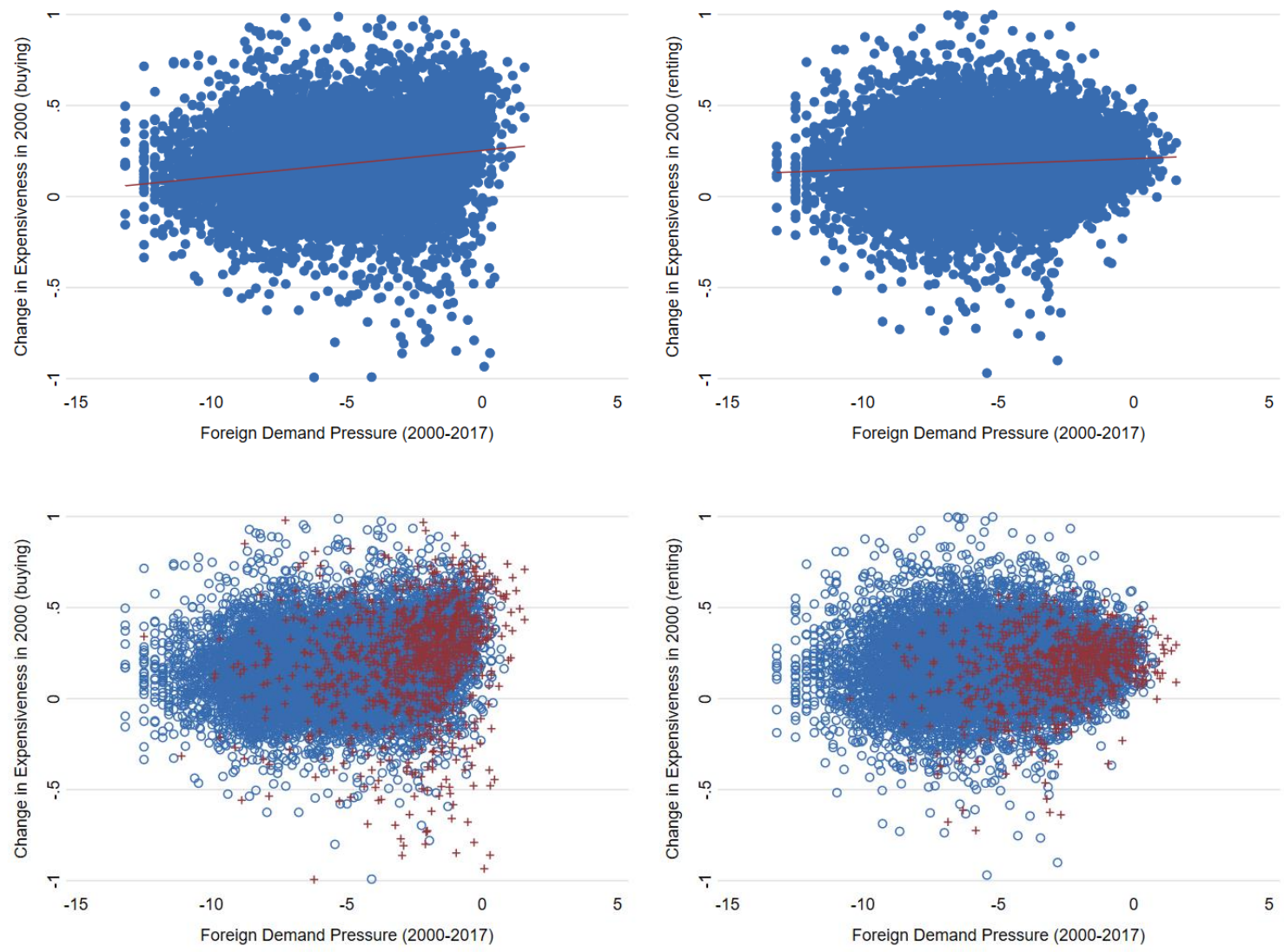

Notes: All variables are reported in logarithmic scale. Red crosses represent the $5 \%$ least affordable ZIP codes in the US in 2000. 
Table 4 - Regression Results

\section{$\Delta \ln (\text { exp_buying })_{i} \quad \Delta \ln \left(\exp \_ \text {renting }\right)_{i}$}

(1)

(2)

$\begin{array}{lcc}\text { Cumulative Foreign Demand Shocks } & 0.00219 & 0.176^{* * *} \\ \text { Expensiveness in } 2000 & (0.00297) & (0.0129) \\ & 0.0403 * * & 0.0298^{* *} \\ \text { Cumulative Foreign Demand Shocks * } & (0.0163) & (0.0141) \\ \text { Expensiveness in 2000 } & 0.0141^{* * *} & 0.0381^{* * *} \\ \text { Constant } & (0.00313) & (0.00297) \\ & 0.215^{* * *} & 0.354 * * * \\ \text { No. of Observations } & (0.0176) & (0.0595) \\ \text { R-squared } & 14,154 & 14,035 \\ & 0.039 & 0.048\end{array}$

Notes: Columns (1) and (2) report results when using the (log) change in buying and renting affordability in ZIP code $i$ between 2000 and 2017 as dependent variable, respectively. Cumulative Foreign Demand Shocks is defined as the sum of our proxy for foreign demand shocks between 2000 and 2017 at the ZIP code level. Expensiveness (buying) is the median home value divided by the median household income in each ZIP code. Expensiveness (renting) the median gross rent divided by the median household income in each ZIP code. Robust standard errors in parentheses. ${ }^{* *} p<0.01,{ }^{* *} p<0.05,{ }^{*} p<0.1$

\section{CONCLUSION}

Because of important data constraints, direct evidence on the effect of foreign demand shocks on local house prices is scant. We circumvent those issues using a novel identification strategy based on the notion of "home bias abroad" in international real estate markets, along with granular data on the foreign exposure of roughly 15.000 US ZIP codes. Following an extreme political crisis event abroad, a proxy for a strong and exogenous shift in foreign demand, we find that house prices rise disproportionately more in US neighborhoods with a high concentration of population originating from the crisis country; which we interpret as (indirect) evidence of the effect of foreign buyers on local house prices. Doing so allows us to contribute to the ongoing debate on the reduction in housing affordability in the US. We find that areas that were already expensive at the end of the 1990s have experienced both the strongest foreign demand shocks and the biggest drop in US housing affordability between 2000 and 2017, suggesting a non-trivial (causal) effect of foreign demand on US house prices over the last 20 years. At the same time, this paper leaves some important questions unanswered. For instance, although foreign demand might have played a role in driving up house prices, we do not explore its broader macroeconomic implications for the local population (e.g. employment or output). We leave those important aspects for further research. 


\section{References}

Agarwal, S., Sing, T. F., \& Wang, L. (2018). Information Asymmetries and Learning in Commercial Real Estate Markets. Available at SSRN: https://ssrn.com/abstract=3022705

Ahearne, A. G., Griever, W. L., \& Warnock, F. E. (2004). Information costs and home bias: an analysis of US holdings of foreign equities. Journal of international economics, 62(2), 313336.

Aizenman, J., \& Jinjarak, Y. (2009). Current account patterns and national real estate markets. Journal of Urban Economics, 66(2), 75-89.

Badarinza, C., \& Ramadorai, T. (2018). Home away from home? Foreign demand and London house prices. Journal of Financial Economics, 130(3), 532-555.

Badarinza, C., Ramadorai, T., \& Shimizu, C. (2019). Gravity, Counterparties, and Foreign Investment. Available at SSRN: https://ssrn.com/abstract=3141255.

Bailey, M., Cao, R., Kuchler, T., Stroebel, J., \& Wong, A., (2017). Measuring Social Connectedness. NBER Working Paper No. 23608.

Borjas, G. J., Freeman R.B., \& Katz, L. F. (1992). On the Labor Market Effects of Immigration and Trade. In Borjas, G. J. \& Freeman, R.B. (ed.) Immigration and the Workforce: Economic Consequences for the United States and Source Areas, pages 213-244 National Bureau of Economic Research, Inc.

Card, D. (2001). Immigrant inflows, native outflows, and the local labor market impacts of higher immigration. Journal of Labor Economics, 19(1), 22-64.

Card, D., and DiNardo, J. (2000). Do Immigrant Inflows Lead to Native Outflows? American Economic Review, 90 (2): 360-367.

Case, K. E. and Shiller, R. J. (1990), Forecasting Prices and Excess Returns in the Housing Market. Real Estate Economics, 18: 253-273.

Cesa-Bianchi, A., Cespedes, L. F. and Rebucci, A. (2015), Global Liquidity, House Prices, and the Macroeconomy: Evidence from Advanced and Emerging Economies. Journal of Money, Credit and Banking, 47: 301-335.

Chinco, A. \& Mayer, C. (2016). Misinformed Speculators and Mispricing in the Housing Market, The Review of Financial Studies, Volume 29, Issue 2, Pages 486-522, 
Coeurdacier, N., and Rey, H. (2013). Home Bias in Open Economy Financial Macroeconomics. Journal of Economic Literature, 51 (1): 63-115.

Cortes, P. (2008). The Effect of Low-Skilled Immigration on U.S. Prices: Evidence from CPI Data. Journal of Political Economy, 116(3), 381-422.

Coval, J. D. and Moskowitz, T. J. (1999), Home Bias at Home: Local Equity Preference in Domestic Portfolios. The Journal of Finance, 54: 2045-2073.

Degen, K. \& Fischer, A.M. (2017). Immigration and Swiss House Prices. Swiss Journal of Economics Statistics (2017) 153: 15.

Dumont, A. M. (2019). Housing Affordability in the U.S.: Trends by Geography, Tenure, and Household Income. FEDS Notes. Washington: Board of Governors of the Federal Reserve System, September 27, 2019,

Favilukis, J. \& Van Nieuwerburgh, S. (2017). Out-of-town Home Buyers and City Welfare. 2017 Meeting Papers 486, Society for Economic Dynamics.

Financial Times, (2017a). Prices of houses in Los Angeles hit a new high. Available at: https://www.ft.com/content/065caba4-bffe-11e7-823b-ed31693349d3.

Financial Times, (2017b). Sky-high prices for towers mask UK property fears. Available at: https://www.ft.com/content/871aef68-78fe-11e7-a3e8-60495fe6ca71.

Financial Times, (2018). Sky-high Hong Kong: can anything stop the property price boom? Available at: https://www.ft.com/content/a6d33890-11a8-11e8-a765-993b2440bd73.

French, K., \& Poterba, J. (1991). Investor Diversification and International Equity Markets. The American Economic Review, 81(2), 222-226.

Garmaise, M. J., \& Moskowitz, T. J. (2004). Confronting Information Asymmetries: Evidence from Real Estate Markets. The Review of Financial Studies, Volume 17, Issue 2, Pages 405437

Glaeser, E.L, La Porta R., Lopez-de Silanes, F., \& Shleifer, A., (2004), "Do institutions cause growth?" Journal of Economic Growth 9 (3), 271-303.

Gonzalez, L., \& Ortega, F. (2013), Immigration and Housing Booms: Evidence from Spain. Journal of Regional Science, 53: 37-59.

Gyourko, J., Mayer, C., \& Sinai, T. (2013). Superstar Cities. American Economic Journal: Economic Policy, 5 (4): 167-99. 
Huberman, G. (2001). Familiarity Breeds Investment. The Review of Financial Studies. Volume 14, Issue 3, 1 Pages 659-680.

International Monetary Fund (2018). IMF Country Report 18/222 - Canada - Selected Issues Papers.

Jinjarak, Y., \& Sheffrin, S. M. (2011). Causality, real estate prices, and the current account. Journal of Macroeconomics, 33(2), 233-246.

Jordà, Ò. (2005). Estimation and Inference of Impulse Responses by Local Projections. American Economic Review, 95 (1): 161-182.

Kurlat, P., \& Stroebel, J. (2015). Testing for Information Asymmetries in Real Estate Markets. The Review of Financial Studies, Volume 28, Issue 8, Pages 2429-2461

Lamont, O., \& Stein, J. (1999). Leverage and House-Price Dynamics in U.S. Cities. The RAND Journal of Economics, 30(3), 498-514.

Levitt, S. D., \& Syverson, C. (2008). Market distortions when agents are better informed: The value of information in real estate transactions. The Review of Economics and Statistics, 90(4), 599-611.

Mian, A. \& Sufi, A. (2009). The Consequences of Mortgage Credit Expansion: Evidence from the U.S. Mortgage Default Crisis, The Quarterly Journal of Economics, Volume 124, Issue 4, Pages 1449-1496

Miyakawa, D., Shimizu, C., \& Uesugi, I. (2016). Geography and Realty Prices: Evidence from International Transaction-Level Data. HIT-REFINED Working Paper Series 52, Institute of Economic Research, Hitotsubashi University.

Peek, J. and Wilcox, J. A. (1991), The Measurement and Determinants of Single-Family House Prices. Real Estate Economics, 19: 353-382. doi:10.1111/1540-6229.00557

Rabanal, P. (2018). An Estimated DSGE Model to Analyze Housing Market Policies in Hong Kong SAR. IMF Working Papers 18/90, International Monetary Fund.

Reinhart, C., \& Reinhart, V. (2008). Capital Flow Bonanzas: An Encompassing View of the Past and Present. NBER International Seminar on Macroeconomics, 5(1), 9-62. doi:10.1086/595995

Sá, F. (2015), Immigration and House Prices in the UK. Economic Journal, 125: 1393-1424. doi:10.1111/ecoj.12158 
Sá, F. and Wieladek, T. (2015), Capital Inflows and the U.S. Housing Boom. Journal of Money, Credit and Banking, 47: 221-256.

Sá, F., Towbin, P. and Wieladek, T. (2014), Capital Inflows, Financial Structure and Housing Booms. Journal of the European Economic Association, 12: 522-546. doi:10.1111/jeea.12047

Saiz, A. (2003). Room in the kitchen for the melting pot: Immigration and rental prices. Review of Economics and Statistics, 85(3), 502-521.

Saiz, A., (2007). Immigration and housing rents in American cities, Journal of Urban Economics, Elsevier, vol. 61(2), pages 345-371, March.

Saiz, A., and Wachter, S. (2011). Immigration and the Neighborhood. American Economic Journal: Economic Policy, 3 (2): 169-88.

Shiller, R. J. (2007). Understanding recent trends in house prices and home ownership. Proceedings - Economic Policy Symposium - Jackson Hole, Federal Reserve Bank of Kansas City, pages $89-123$.

Suher, M. (2016). Is Anybody Home? The Impact and Taxation of Non-Resident Buyers. Furman Center for Real Estate and Urban Policy, NYU Working Paper.

Van Nieuwerburgh, S., \& Veldkamp, L. (2009), Information Immobility and the Home Bias Puzzle. The Journal of Finance, 64: 1187-1215. 


\section{APPENDIX A - Data and Stylized Facts}

\section{Table A.1: List of Source Countries (EMDEs)}

The countries reported below are countries for which data (i) on political risks and (ii) from the US census - to compute the share of foreign-born population originating from that country- are available. Sources are reported in the text (See Section I). See Figure A.1 for summary statistics.

\begin{tabular}{cc}
\hline Argentina & Iraq \\
Armenia & Israel \\
Bangladesh & Jamaica \\
Belarus & Jordan \\
Bolivia & Lebanon \\
Brazil & Malaysia \\
Chile & Mexico \\
China & Nigeria \\
Colombia & Pakistan \\
Costa Rica & Panama \\
Cuba & Peru \\
Czechoslovakia & Philippines \\
Dominican Republic & Poland \\
Ecuador & Romania \\
Egypt & Russia \\
El Salvador & Serbia \\
Ethiopia & Sierra Leone \\
Ghana & South Africa \\
Guatemala & South Korea \\
Guyana & Syria \\
Haiti & Taiwan \\
Honduras & Thailand \\
Hungary & Turkey \\
India & Ukraine \\
Indonesia & Venezuela \\
Iran & Vietnam \\
\hline \hline & \\
\hline
\end{tabular}


Figure A.1: Share of US residents, by country of origin

The figure reports the total number of foreign-born population (as $\%$ of the US population) by country in 2000, according to the Census.

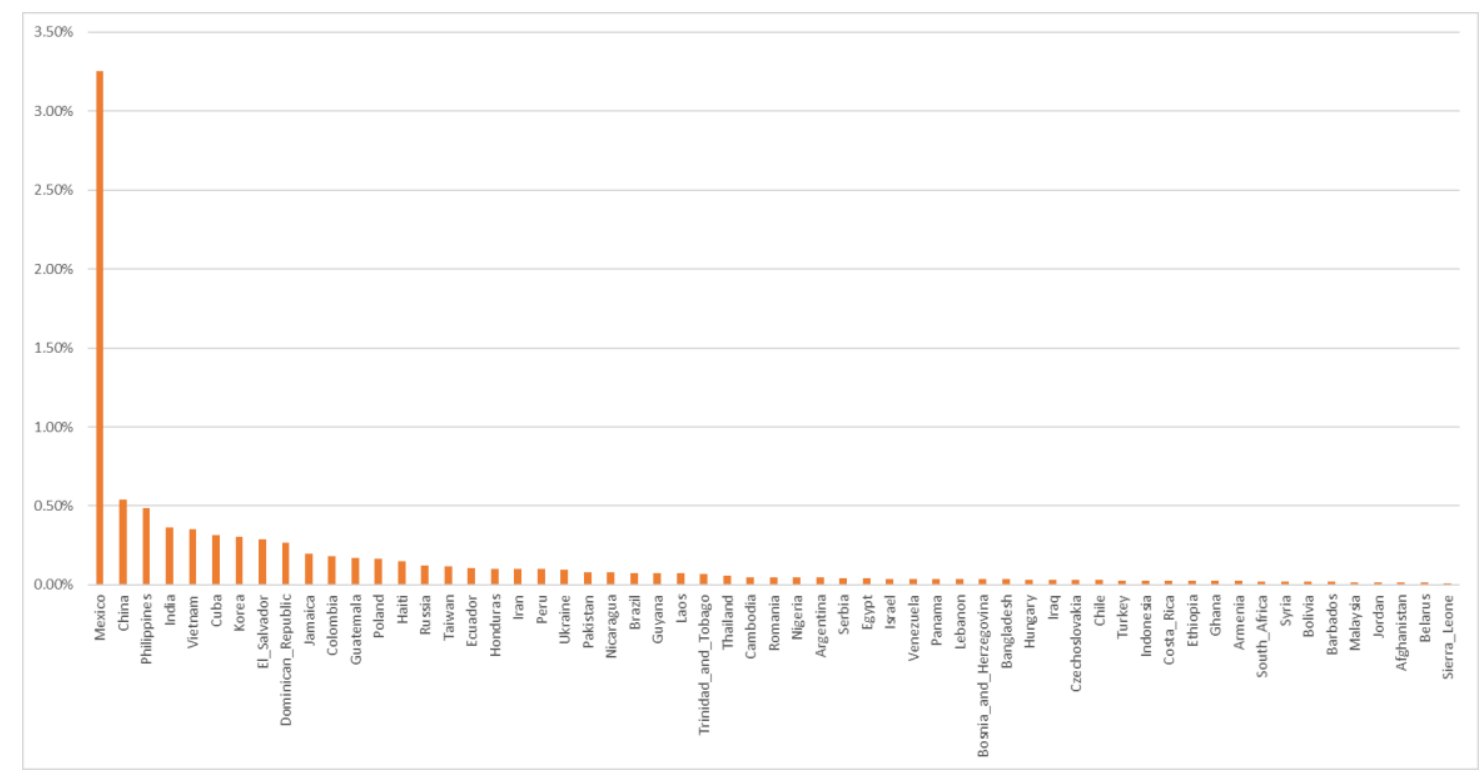

Figure A.2: ICRG Political Risk Ratings - Methodology

The figure reports the dimensions scored in the ICRG Political Rating. To construct a version of the cycle that is uncorrelated to the global financial cycle (and the US), sub-components B and $\mathrm{C}$ (Investment profile and Socioeconomic conditions) have been purged from the original ratings for all countries. Figure A3 plots a comparison of both ratings in the case of Russia.

\begin{tabular}{clr}
\hline \multicolumn{2}{c}{$\begin{array}{c}\text { POLITICAL RISK COMPONENTS } \\
\text { Component }\end{array}$} & $\begin{array}{c}\text { Points } \\
\text { (max.) }\end{array}$ \\
\hline$*$ A & Government Stability & 12 \\
$*$ B & Socioeconomic Conditions & 12 \\
$*$ C & Investment Profile & 12 \\
$*$ D & Internal Conflict & 12 \\
$*$ E & External Conflict & 12 \\
F & Corruption & 6 \\
G & Military in Politics & 6 \\
H & Religious Tensions & 6 \\
I & Law and Order & 6 \\
J & Ethnic Tensions & 6 \\
K & Democratic Accountability & 6 \\
L & Bureaucracy Quality & 4 \\
Total & & 100 \\
\hline
\end{tabular}


Figure A3: Political shocks in Russia

To illustrate how we construct foreign political shocks, the figure below plots the raw ICRG political rating along with our (purged) index (PRIP). Grey shaded areas indicate when the PRIP crosses the $95^{\text {th }}$ percentile, and therefore the foreign political shocks used in the case of Russia in our analysis. As discussed in Section 2, purging the raw indexes from their socioeconomic conditions and investment profile sub-indexes is important, since they move closely with international borrowing costs and more generally with global economic events that are linked to US conditions (such as the 2008-2009 Global Financial crisis). Our final measures of shocks - and their timing - also capture well idiosyncratic and extreme political events in Russia over that period, such as the second Chechen war and the resignation of Boris Yeltsin (in late 1999), or the sanctions imposed on Russia in early 2014.

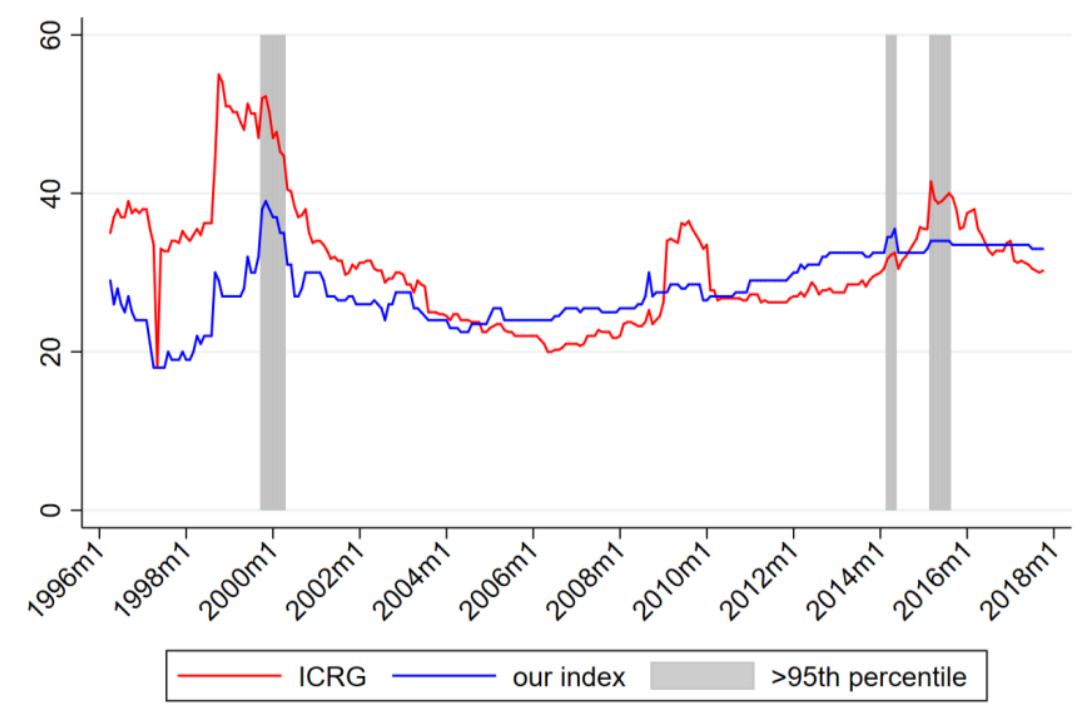




\section{APPENDIX B - Additional Results}

This appendix replicates our analysis using an alternative foreign exposure measure based on Badarinza and Ramadorai (2018), who assess the exposure of a ZIP code to a foreign country using the share of the local population originating from that country as weights attached to foreign political shocks. Formally:

$$
F_{i, c}=F B_{i, c} / P_{o p}
$$

where $P o p_{i}$ denotes the total population in ZIP code $i$, measured the 2000 US census. Overall, we find that our key results are broadly unchanged. If anything, our results get stronger, both economically and statistically, when using the new weighting system. This can be seen in Table B.1, Figure B.1, Figure B.2 and Figure B.3 below, which are the counterparts of Table 1, Figure 3, Figure 4 and Figure 5 in the main text, respectively.

Table B.1: Baseline results - Alternative exposure measure

\begin{tabular}{|c|c|c|c|c|c|}
\hline & \multicolumn{5}{|c|}{$\Delta \ln (h p)_{i, t}$} \\
\hline & (1a) & (1b) & $(2)$ & (3) & (4) \\
\hline \multirow[t]{2}{*}{$F D_{i, t-1}$} & $0.00283 * * *$ & $0.00137^{* * *}$ & $0.00101 * * *$ & 0.000231 & $0.000702 * *$ \\
\hline & $(-0.000343)$ & $(-0.000284)$ & $(-0.000281)$ & $(-0.000284)$ & $(-0.00029)$ \\
\hline \multirow{2}{*}{$F D_{i, t-2}$} & $-0.00162 * * *$ & $-0.000747 * *$ & $-0.000755^{* *}$ & $-0.000728^{*}$ & -0.000208 \\
\hline & $(-0.000389)$ & $(-0.000373)$ & $(-0.000373)$ & $(-0.000374)$ & $(-0.000388)$ \\
\hline \multirow[t]{2}{*}{$F D_{i, t-3}$} & $0.00204 * * *$ & $0.00143 * * *$ & $0.00125^{* * *}$ & $0.000847^{* * *}$ & $0.00119 * * *$ \\
\hline & $(-0.000301)$ & $(-0.000283)$ & $(-0.000282)$ & $(-0.000281)$ & $(-0.0003)$ \\
\hline \multirow{2}{*}{$\sum F_{i, c} \times V I X_{t-1}$} & & & $-0.0250 * * *$ & & \\
\hline & & & $(-0.00211)$ & & \\
\hline \multirow{2}{*}{$\stackrel{c}{I M} R_{i} \times V I X_{t-1}$} & & & & $-0.00413 * * *$ & \\
\hline & & & & $(-0.000125)$ & \\
\hline \multirow[t]{2}{*}{ Constant } & $0.000203 * * *$ & $0.000345 * * *$ & $0.000595 * * *$ & $0.00120 * * *$ & $0.000413 * * *$ \\
\hline & $(-5.77 E-05)$ & $(-4.48 \mathrm{E}-05)$ & $(-4.96 \mathrm{E}-05)$ & $(-5.21 E-05)$ & $(-3.84 \mathrm{E}-05)$ \\
\hline No. of observations & $3,407,334$ & $3,376,332$ & $3,376,332$ & $3,376,332$ & $3,376,332$ \\
\hline R-squared & 0.714 & 0.775 & 0.775 & 0.775 & 0.776 \\
\hline No. of ZIP codes & 14,993 & 14,993 & 14,993 & 14,993 & 14,993 \\
\hline $\begin{array}{l}\text { No. of lags of } \\
\Delta \ln (h p)\end{array}$ & 2 & 4 & 4 & 4 & 4 \\
\hline Time FE & YES & YES & YES & YES & NO \\
\hline ZIP code FE & YES & YES & YES & YES & YES \\
\hline $\mathrm{L}, \mathrm{M}, \mathrm{H} \times$ Time $\mathrm{FE}$ & NO & NO & NO & NO & YES \\
\hline
\end{tabular}

Notes: Robust standard errors in parentheses. ${ }^{* * *} p<0.01,{ }^{* *} p<0.05,{ }^{*} p<0.1 . \mathrm{L}, \mathrm{M}$ and $\mathrm{H}$ refer to fixed effects that vary by low $(\mathrm{L})$, medium $(\mathrm{M})$, and high $(\mathrm{H})$ immigrant concentration - based on the IMR measure. 
Figure B.1: Cumulative Effects of Foreign Demand Shocks on Local House Prices Alternative exposure measure

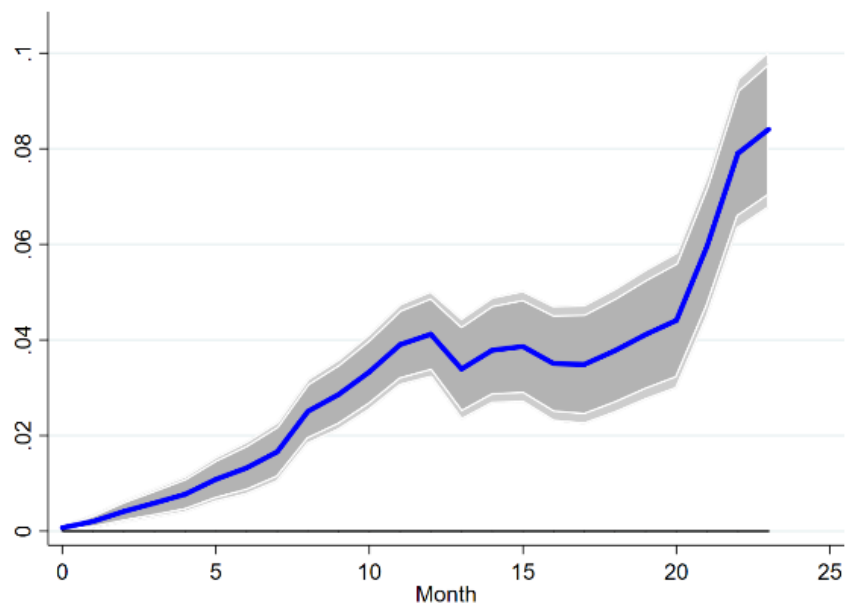

Notes: The vertical axis shows the cumulative growth of ZIP code-level house prices following a shock. Shaded areas report $90 \%$ and $95 \%$ confidence intervals, respectively.

Figure B.2: Foreign Demand Shocks and ZIP-Code Affordability in 2000 - Alternative exposure measure
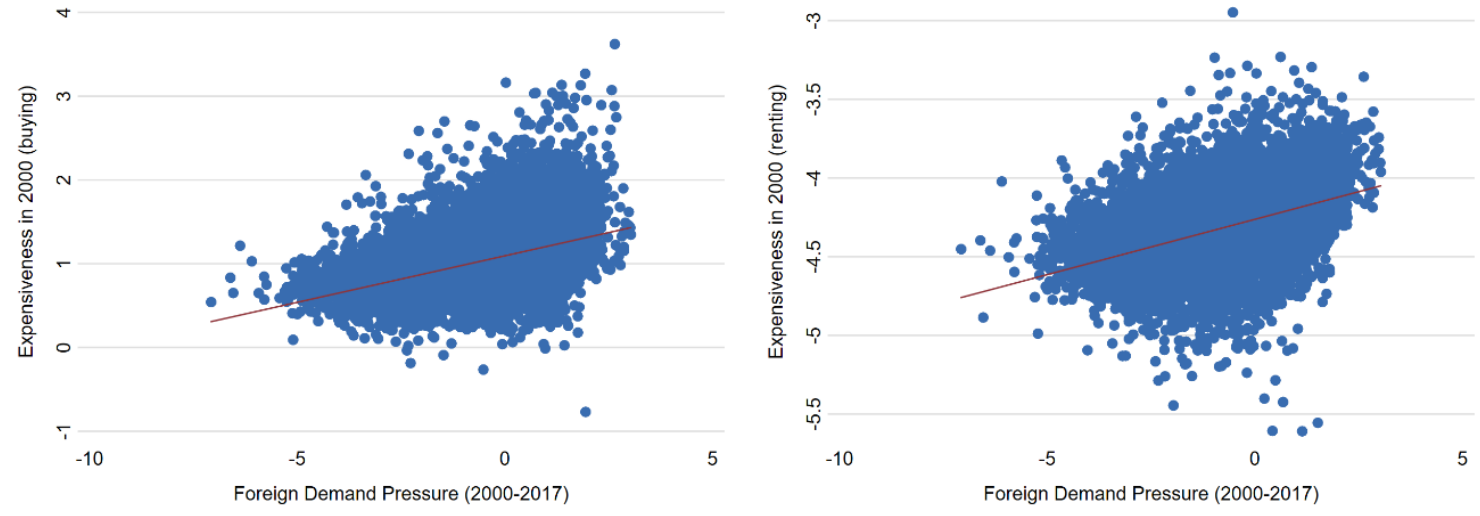
Figure B.3: Foreign Demand Shocks and Change in ZIP-code Affordability (2000- 2017) Alternative exposure measure
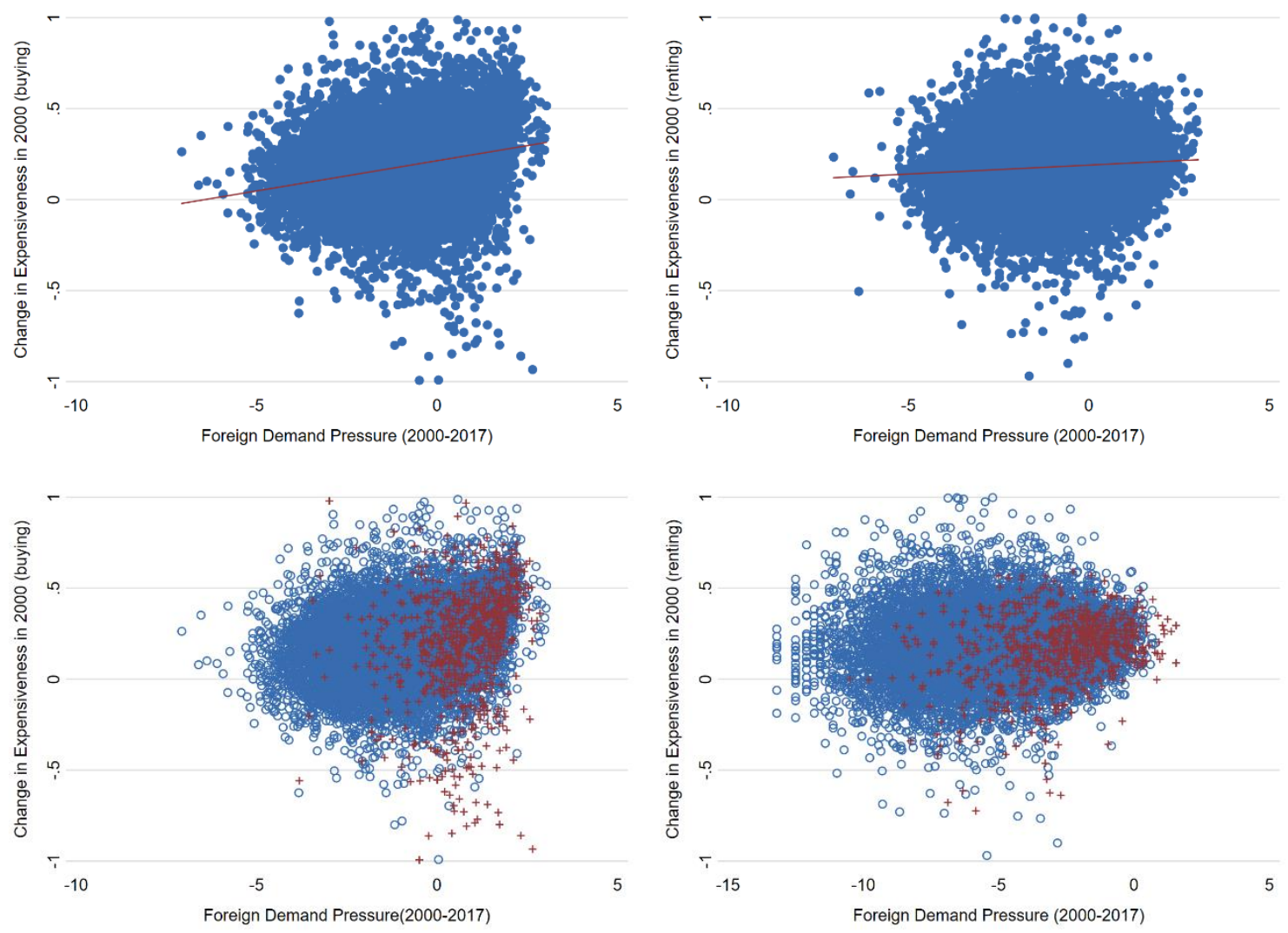